\title{
PENGARUH PERCEIVED QUALITY, BRAND IMAGE, BRAND TRUST TERHADAP PUCHASE INTENTION PRODUK MILO
}

\author{
Edward danTommy Setiawan Ruslim \\ Program S1 Manajemen Fakultas Ekonomi dan Bisnis Universitas Tarumanagara \\ Email : edwardtjeng17@gmail.com
}

\begin{abstract}
This study aims to decide the effect of perceived quality, brand image, and brand trust on purchase intention on halal milo milk in Jakarta. I choose Milo because Milo is the lowest in top brand award, losing to it's rival like Ultra Milk, Bear Brand, etc. The population of this study is the consumers which is domiciled in Jakarta. The sample of this study was gathered using a questionnaire method, which were given to 100 respondents. The analysis of data used in this study is a Partial Least Square assisted by the SmartPLS 3.0 Program. The result of this study are perceived quality, brand image, and brand trust have a positive and significant effect on purchase intention of halal milo milk product in Jakarta.
\end{abstract}

Keywords : perceived quality, brand image, brand trust, purchase intention

Abstrak: Tujuan dari penelitian ini adalah untuk menentukan efek dari persepsi kualitas, citra merek, dan kepercayaan merek terhadap intensi pembelian pada pada produk susu halal Milo di Jakarta. Peneliti memilih Milo karena Milo menduduki posisi terendah di top brand award, kalah dengan para pesaing seperti Ultra Milk, Bear Brand, dan lain-lain. Populasi dari penelitian adalah konsumen yang mengkonsumsi susu serta berdomisili di Jakarta Barat. Sampel dikumpulkan menggunakan metode kuesioner, yang mana di berikan kepada 100 responden. Teknik analisis data yang di gunakan dalam penelitian ini adalah Partial Least Square yang di gunakan dalam aplikasi SmartPLS 3.0. Hasil dari penelitian ini adalah persepsi kualitas, citra merek, dan kepercayaan merek memiliki pengaruh terhadap intensi pembelian pada produk susu halal Milo di Jakarta.

Kata Kunci : persepsi kualitas, citra merek, kepercayaan merek, intensi pembelian

\section{LATAR BELAKANG}

Makanan-makanan yang terdapat pada jenis empat sehat lima sempurna yaitu tipe konsumsi yang sangat penting dan dibutuhkan oleh tubuh manusia untuk memperoleh tubuh yang sehat dan kuat, hidangan tipe tersebut memiliki kandungan yang mencukupi, seperti karbohidrat yang penting bagi tubuh untuk menghasilkan energi, protein yang berfungsi untuk menciptakan enzim serta menciptakan sistem kekebalan pada tubuh, serta vitamin dan mineral yang berfungsi untuk membuat tubuh sehat. Makanan yang termasuk ke jenis tersebut yaitu buah-buahan, sayur-sayuran, lauk pauk, dan susu.

Susu termasuk satu bagian dari jenis makanan empat sehat lima sempurna yang sangat penting bagi tubuh. Susu kaya akan kandungan yang mana dibutuhkan oleh tubuh yakni protein, mineral, vitamin, dan karbohidrat, sehingga susu dijadikan asupan nutrisi yang penting bagi manusia, terutama yang berusia muda karena dalam masa pertumbuhan, sangat 
dibutuhkan gizi yang tinggi. Susu juga memiliki manfaat bagi orang tua, karena susu memiliki kandungan kalsium yang tinggi sehingga susu sangat berguna bagi kesehatan tulang pada tubuh manusia terutama yang sudah berumur untuk mencegah keropos dan untuk menciptakan tulang yang kuat, dan sehat.

Dijaman sekarang karena pandemi yang sedang terjadi, manusia sedang mengalami masa dimana sulit untuk mendapatkan bahan pokok makanan salah satunya susu, sehingga banyak orang yang membeli bahan pangan seperti beras, lauk pauk, dan susu dalam jumlah yang banyak dengan tujuan untuk mencegah kehabisan bahan pangan.

Terdapat banyak jenis perusahaan yang memproduksi susu, dan sudah dikenal oleh banyak orang akan kualitas susunya dan rasa susunya yang enak, yaitu seperti produk susu Ultra Milk, Frisian Flag, Indomilk, Bear Brand, Milo, Diamonds, Greenfields, dan lain-lain. Perusahaan-perusahaan tersebut saling bersaing dalam mempertahankan dan meningkatkan konsumen yang sudah dicapainya.

Tabel 1.1 Data Penjualan Susu Dalam Kemasan

\begin{tabular}{|l|l|l|}
\hline Merek & $\mathbf{2 0 1 9}$ & $\mathbf{2 0 2 0}$ \\
\hline Ultra Milk & $42,7 \%$ & $31,8 \%$ \\
\hline Frisian Flag & $17,2 \%$ & $21,9 \%$ \\
\hline Indomilk & $12,5 \%$ & $14,5 \%$ \\
\hline Bear Brand & $12,3 \%$ & $14,3 \%$ \\
\hline Milo & $4,8 \%$ & $5,3 \%$ \\
\hline
\end{tabular}

Sumber : (http://www.topbrand-award.com)

Salah satu perusahaan pencipta produk susu yang saat ini kalah dalam bersaing dengan para pesaing (competitor) adalah produk susu Milo yang diciptakan oleh PT Nestlé Indonesia. Masalah yang dialami oleh produk susu Milo adalah rendahnya peminat dari para konsumen terhadap produk susu Milo, konsumen cenderung lebih memilih produk lain seperti Bear Brand, Indomilk, dan lain lain yang mana menyebabkan Milo berada di posisi terendah.

Berdasarkan penjelasan diatas maka peneliti tertarik untuk membuat jurnal penelitian dengan judul "Pengaruh Perceived Quality, Brand Image, Brand Trust Terhadap Puchase Intention Produk Milo".

\section{KAJIAN TEORI}

Teori yang berkaitan dengan purchase intention konsumen untuk mengkonsumsi suatu produk adalah the theory of planned behavior (TPB). Teori ini merupakan perpanjangan dari the theory of reasoned action (TRA) yang mana merupakan teori yang lebih awal. The theory of reasoned action (TRA) merupakan teori yang diciptakan oleh Ajzen. Dalam the theory of reasoned action (TRA) perilaku konsumen ditentukan oleh niatan (intention). Oleh karena itu penulis dapat menyimpulkan bahwa perilaku konsumen berkaitan kuat dengan purchase intention konsumen. Dalam the theory of planned behavior (TPB) niat untuk bertindak 
diasumsikan dapat menangkap faktor motivasi yang dapat mempengaruhi perilaku konsumen, dan juga indikasi seberapa besar usaha konsumen dalam merencanakan perilaku.

\section{Definisi konseptual variabel perceived quality}

Menurut Qualls dan Rosa (1995) perceived quality adalah satu set atribut atau kemampuan yang merujuk pada suatu merek maupun kualitas produk. Menurut Boulding, Kalra, Staelin, Zeithaml, dan Kirmani (1993) perceived quality adalah fondasi persepsi konsumen terhadap kualitas produk secara keseluruhan.

Definisi konseptual variabel brand image

Menurut Wu dan Wang (2014) brand image adalah gambaran atau citra perusahaan dalam lingkup publik, yang terlihat berdasarkan evaluasi konsumen dan kesadaran perusahaan atau merek dalam sebuah pasar. Menurut Hong et al (2002) brand image merupakan gambaran konsumen mengenai suatu merek tertentu, yang dijadikan konsumen referensi penting untuk membuat keputusan pembelian.

\section{Definisi konseptual variabel brand trust}

Menurut Chaudburi dan Holbrook (2001) brand trust adalah tingkatan kesediaan konsumen dalam memberikan rasa percaya terhadap suatu produk bahwa produk tersebut dapat bekerja sesuai fungsi yang dispesifikasikannya. Menurut Agustin dan Singh (2005) brand trust memiliki arti yaitu keyakinan konsumen dalam mengandalkan pihak penjual bahwa pihak penjual akan menyediakan servis sesuai dengan yang sudah dijanjikan.

Kaitan antara perceived quality terhadap purchase intention

Tabel 2.1

Penelitian relevan perceived quality terhadap purchase intention

\begin{tabular}{|c|c|c|c|}
\hline No & Nama Peneliti & Metode Penelitian & Hasil Penelitian \\
\hline 1. & $\begin{array}{l}\text { Afzaal Ali, Guo } \\
\text { Xiaoling, dan } \\
\text { Mehkar Sherwani }\end{array}$ & $\begin{array}{l}\text { Metode : structural } \\
\text { equation modelling, } \\
\text { sampel : } 347, \\
\text { penelitian dilakukan } \\
\text { di Pakistan. }\end{array}$ & $\begin{array}{l}\text { Perceived quality } \\
\text { berpengaruh positif } \\
\text { terhadap purchase } \\
\text { intention konsumen. }\end{array}$ \\
\hline 2. & $\begin{array}{l}\text { Yuslina Liza } \\
\text { Mohd Yusof }\end{array}$ & $\begin{array}{l}\text { Metode : purposive } \\
\text { sampling, sampel : } \\
\text { 531, penelitian } \\
\text { dilakukan di } \\
\text { Malaysia }\end{array}$ & $\begin{array}{c}\text { Perceived quality } \\
\text { berpengaruh positif } \\
\text { dan signifikan } \\
\text { terhadap purchase } \\
\text { intention }\end{array}$ \\
\hline 3. & Yufan li & $\begin{array}{l}\text { Metode : structural } \\
\text { equation, sampel : } \\
\text { 345, penelitian } \\
\text { dilakukan di Taiwan }\end{array}$ & $\begin{array}{l}\text { Perceived quality } \\
\text { berpengaruh positif } \\
\text { terhadap purchase } \\
\text { intention }\end{array}$ \\
\hline
\end{tabular}


Kaitan antara brand image terhadap purchase intention

Tabel 2.2

Penelitian relevan brand image terhadap purchase intention

\begin{tabular}{|c|c|c|c|}
\hline No. & Nama Peneliti & Metode Penelitian & Hasil Penelitian \\
\hline 1. & $\begin{array}{c}\text { Afzaal Ali, Guo } \\
\text { Xiaoling, dan } \\
\text { Mehkar Sherwani }\end{array}$ & $\begin{array}{l}\text { Metode : structural } \\
\text { equation modelling, } \\
\text { sampel : } 347, \\
\text { penelitian dilakukan } \\
\text { di Pakistan. }\end{array}$ & $\begin{array}{c}\text { Brand image } \\
\text { berpengaruh positif } \\
\text { terhadap purchase } \\
\text { intention konsumen. }\end{array}$ \\
\hline 2. & $\begin{array}{c}\text { Mohammad Reza } \\
\text { Jalilvand }\end{array}$ & $\begin{array}{c}\text { Metode : survey, } \\
\text { sampel : } 341, \\
\text { penelitian dilakukan } \\
\text { di Iran }\end{array}$ & $\begin{array}{l}\text { Brand image } \\
\text { berpengaruh positif } \\
\text { terhadap purchase } \\
\text { intention. }\end{array}$ \\
\hline 3. & $\begin{array}{c}\text { Safeena Yaseen, } \\
\text { dan Ibtesam } \\
\text { Mazahir }\end{array}$ & $\begin{array}{c}\text { Metode : SPSS, } \\
\text { sampel : } 126, \\
\text { penelitian dilakukan } \\
\text { di Pakistan }\end{array}$ & $\begin{array}{l}\text { Brand image memiliki } \\
\text { pengaruh positif } \\
\text { terhadap purchase } \\
\text { intention }\end{array}$ \\
\hline 4. & $\begin{array}{c}\text { Tommy Setiawan } \\
\text { Ruslim, dan } \\
\text { Richard Andrew }\end{array}$ & $\begin{array}{c}\text { Metode : SPSS, } \\
\text { Sampel : } 50, \\
\text { penelitian dilakukan } \\
\text { di Jakarta }\end{array}$ & $\begin{array}{c}\text { Brand image memiliki } \\
\text { pengaruh yang } \\
\text { signifikan terhadap } \\
\text { purchase intention }\end{array}$ \\
\hline
\end{tabular}

Kaitan antara brand trust terhadap purchase intention

Tabel 2.3

Penelitian relevan brand trust terhadap purchase intention

\begin{tabular}{|c|c|c|c|}
\hline No. & Nama Peneliti & Metode Penelitian & Hasil Penelitian \\
\hline 1. & $\begin{array}{c}\text { Afzaal Ali, Guo } \\
\text { Xiaoling, dan } \\
\text { Mehkar } \\
\text { Sherwani }\end{array}$ & $\begin{array}{l}\text { Metode : structural } \\
\text { equation modelling, } \\
\text { sampel : } 347, \\
\text { penelitian dilakukan di } \\
\text { Pakistan. }\end{array}$ & $\begin{array}{l}\text { Brand trust } \\
\text { berpengaruh positif } \\
\text { terhadap purchase } \\
\text { intention konsumen. }\end{array}$ \\
\hline 2. & $\begin{array}{c}\text { Enrique P. } \\
\text { Beccera }\end{array}$ & $\begin{array}{c}\text { Metode : test, sampel : } \\
\text { 422, penelitian } \\
\text { dilakukan di Texas. }\end{array}$ & $\begin{array}{l}\text { Hasil dari penelitian } \\
\text { ini adalah trust } \\
\text { memiliki pengaruh } \\
\text { yang positif dan } \\
\text { signifikan terhadap } \\
\text { purchase intention. }\end{array}$ \\
\hline 3. & Nadia Jimenez & $\begin{array}{l}\text { Metode : structural } \\
\text { equation modelling, } \\
\text { sampel : 476, } \\
\text { penelitian dilakukan di } \\
\text { Mexico dan Spain. }\end{array}$ & $\begin{array}{l}\text { Hasil dari penelitian } \\
\text { ini adalah trust } \\
\text { memiliki pengaruh } \\
\text { yang positif dan } \\
\text { signifikan terhadap } \\
\text { purchase intention. }\end{array}$ \\
\hline
\end{tabular}




\begin{tabular}{|c|c|c|c|}
\hline 4. & Hendri, dan & Metode : structural \\
Herlina Budiono & $\begin{array}{c}\text { Hasil dari penelitian } \\
\text { sampel : } 100 \\
\end{array}$ & $\begin{array}{c}\text { responden, penelitian } \\
\text { dilakukan di Jakarta }\end{array}$ & $\begin{array}{c}\text { yang positif terhadap } \\
\text { memiliki pengaruh } \\
\text { purchase intention. }\end{array}$ \\
\hline
\end{tabular}

Berdasarkan tabel pada halaman-halaman sebelumnya mengenai penelitian relevan yang berisi tentang penelitian-penelitian yang telah dilakukan oleh beberapa peneliti sebelumnya mengenai perceived quality, brand image, dan brand trust, purchase intention pada berbagai industri yang berbeda-beda dapat diketahui bahwa perceived quality, brand image, dan brand trust memiliki pengaruh terhadap purchase intention

Hipotesis pada jurnal ini adalah

H1: Perceived quality memiliki pengaruh yang positif terhadap purchase intention pada produk susu halal Milo di Jakarta.

$\mathrm{H} 2$ : Brand image memiliki pengaruh yang positif terhadap purchase intention pada produk susu halal Milo di Jakarta.

H3: Brand trust memiliki pengaruh yang positif terhadap purchase intention pada produk susu halal Milo di Jakarta.

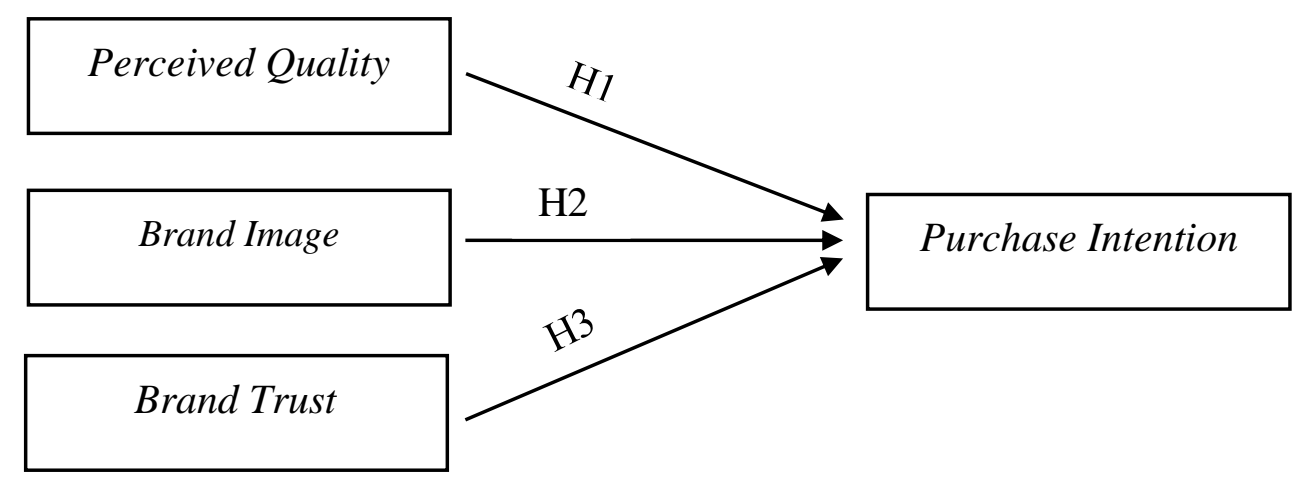

Gambar 2.1

Model Penelitian

\section{METODOLOGI}

Subjek dari penelitian ini adalah para konsumen yang telah mencoba produk susu halal Milo, dan berdomisili di Jakarta. Deskripsi responden akan dilihat berdasarkan beberapa karakteristik, seperti jenis kelamin, usia, pendapatan, status pernikahan, pendidikan terakhir, dan status pekerjaan lainnya.

Objek pada penelitian ini yaitu, hasil tanggapan 250 responden terhadap setiap indikator yang berkaitan dengan variabel yang digunakan dalam penelitian ini, yaitu perceived quality, brand image, brand trust, dan purchase intention.

Operasionalisasi Variabel pada penelitian ini adalah sebagai berikut 
Tabel 3.1 Operasionalisasi variabel perceived quality

\begin{tabular}{|l|l|l|l|}
\hline \multicolumn{1}{|c|}{ Variabel } & \multicolumn{1}{|c|}{ Indikator } & Kode & Skala \\
\hline $\begin{array}{l}\text { Perceived } \\
\text { Quality }\end{array}$ & Susu halal saya saat ini memiliki kualitas yang baik & PQ1 & Interval \\
\cline { 2 - 3 } & $\begin{array}{l}\text { Susu halal saya saat ini memiliki kualitas yang } \\
\text { konsisten }\end{array}$ & PQ2 & \\
\cline { 2 - 3 } & $\begin{array}{l}\text { Susu halal saya saat ini sangat dapat diandalkan } \\
\text { dari segi kualitas }\end{array}$ & PQ3 & \\
\cline { 2 - 3 } & $\begin{array}{l}\text { Susu halal saya saat ini memiliki kandungan gizi } \\
\text { yang baik }\end{array}$ & PQ4 & \\
\hline
\end{tabular}

Tabel 3.2 Operasionalisasi variabel brand image

\begin{tabular}{|c|c|c|c|}
\hline Variabel & Pernyataan & Kode & Skala \\
\hline \multirow[t]{4}{*}{$\begin{array}{l}\text { Brand } \\
\text { Image }\end{array}$} & $\begin{array}{l}\text { Merek susu halal saya saat ini merupakan merek } \\
\text { terbaik yang memiliki janji halal }\end{array}$ & BI1 & \multirow[t]{4}{*}{ Interval } \\
\hline & $\begin{array}{l}\text { Merek susu halal saya saat ini memiliki reputasi } \\
\text { yang baik dibanding para pesaing }\end{array}$ & BI2 & \\
\hline & $\begin{array}{l}\text { Merek susu halal saya saat ini mengatasi semua } \\
\text { kekhawatiran masalah halal saya }\end{array}$ & $\mathrm{BI} 3$ & \\
\hline & $\begin{array}{l}\text { Merek susu halal saya saat ini dapat dipercaya } \\
\text { mengenai janji halalnya }\end{array}$ & BI4 & \\
\hline
\end{tabular}

Tabel 3.3 Operasionalisasi variabel brand trust

\begin{tabular}{|l|l|l|c|}
\hline Variabel & \multicolumn{1}{|c|}{ Pernyataan } & Kode & Skala \\
\hline $\begin{array}{l}\text { Brand } \\
\text { trust }\end{array}$ & Saya percaya pada merek susu halal saya saat ini & BT1 & Interval \\
\cline { 2 - 3 } & $\begin{array}{l}\text { Saya memberikan kepercayaan hanya pada merek } \\
\text { susu halal saya saat ini }\end{array}$ & BT2 & \\
\cline { 2 - 3 } & $\begin{array}{l}\text { Merek susu halal saya saat ini adalah merek yang } \\
\text { jujur }\end{array}$ & BT3 & \\
\hline
\end{tabular}




\begin{tabular}{|l|l|l|l|}
\hline & $\begin{array}{l}\text { Merek susu halal saya saat ini merupakan merek } \\
\text { yang aman untuk dikonsumsi }\end{array}$ & BT4 & \\
\hline
\end{tabular}

Menurut Sugiyono (2019) mengemukakan bahwa populasi adalah wilayah generalisasi yang terdiri atas obyek atau subyek yang memiliki kualitas maupun karakteristik tertentu yang ditentukan oleh peneliti untuk diteliti, dan selanjutnya dijadikan sebagai kesimpulan.

Menurut Sugiyono (2019), sampel adalah sebagian atau sejumlah karakteristik yang dimiliki oleh populasi tersebut. Jumlah anggota sampel sering dinyatakan dengan ukuran sampel. Ukuran sampel yang layak digunakan dalam suatu penelitian adalah antara 30 sampai dengan 500 sampel, maka responden yang digunakan adalah 250 responden konsumen susu di Jakarta. Metode sampling yang digunakan adalah purposive sampling yang mana merupakan teknik penentuan sampel dengan pertimbangan tertentu.

Pengujian statistik dilakukan menggunakan aplikasi pengolah data SmartPLS versi 3.0.

\section{HASIL ANALISIS DATA}

Uji Validitas

Tabel 4.1 Nilai AVE

\begin{tabular}{|c|c|}
\hline Variabel & AVE \\
\hline Perceived Quality & 0,491 \\
\hline Brand Image & 0,585 \\
\hline Brand Trust & 0,526 \\
\hline Purchase Intention & 0,751 \\
\hline
\end{tabular}

Sumber: Lampiran

Berdasarkan tabel nilai AVE pada halaman sebelumnya dapat diketahui bahwa nilai dari perceived quality kurang dari 0,5 dan hasil loading factor memberikan hasil warna merah, oleh karena itu penulis memutuskan untuk memodifikasi yaitu dengan melakukan penghapusan indikator.

Tabel 4.2 Hasil Loading Factor

\begin{tabular}{|l|l|l|l|l|}
\hline & PQ & BI & BT & PI \\
\hline PQ1 & 0,758 & & & \\
\hline PQ2 & 0,759 & & & \\
\hline PQ3 & 0,631 & & & \\
\hline PQ4 & 0,642 & & & \\
\hline BI1 & & 0,771 & & \\
\hline BI2 & & 0,770 & & \\
\hline BI3 & & 0,664 & & \\
\hline BI4 & & 0,843 & & \\
\hline BT1 & & & 0,828 & \\
\hline
\end{tabular}


Edward dan Ruslim: Pengaruh Perceived Quality, Brand Image...

\begin{tabular}{|l|l|l|l|l|}
\hline BT2 & & & 0,563 & \\
\hline BT3 & & & 0,834 & \\
\hline BT4 & & & 0,639 & \\
\hline PI1 & & & & 0,871 \\
\hline PI2 & & & & 0,887 \\
\hline PI3 & & & & 0,842 \\
\hline
\end{tabular}

Sumber : Lampiran

Tabel 4.3 Nilai Average Variance Extracted (AVE) Setelah Modifikasi

\begin{tabular}{|c|c|}
\hline Variabel & AVE \\
\hline Perceived Quality & 0,557 \\
\hline Brand Image & 0,585 \\
\hline Brand Trust & 0,526 \\
\hline Purchase Intention & 0,751 \\
\hline
\end{tabular}

Tabel 4.4 Hasil Cross Loading

\begin{tabular}{|l|l|l|l|l|}
\hline & PQ & BI & BT & PI \\
\hline PQ1 & $\mathbf{0 , 7 9 6}$ & 0,438 & 0,531 & 0,331 \\
\hline PQ2 & $\mathbf{0 , 7 4 2}$ & 0,481 & 0,454 & 0,281 \\
\hline PQ4 & $\mathbf{0 , 6 9 6}$ & 0,358 & 0,413 & 0,322 \\
\hline BI1 & 0,363 & $\mathbf{0 , 7 7 1}$ & 0,450 & 0,353 \\
\hline BI2 & 0,439 & $\mathbf{0 , 7 7 0}$ & 0,503 & 0,373 \\
\hline BI3 & 0,347 & $\mathbf{0 , 6 6 4}$ & 0,399 & 0,250 \\
\hline BI4 & 0,557 & $\mathbf{0 , 8 4 3}$ & 0,637 & 0,427 \\
\hline BT1 & 0,509 & 0,552 & $\mathbf{0 , 8 2 8}$ & 0,542 \\
\hline BT2 & 0,383 & 0,457 & $\mathbf{0 , 5 6 2}$ & 0,354 \\
\hline BT3 & 0,486 & 0,543 & $\mathbf{0 , 8 3 4}$ & 0,498 \\
\hline BT4 & 0,441 & 0,329 & $\mathbf{0 , 6 3 9}$ & 0,293 \\
\hline PI1 & 0,416 & 0,408 & 0,589 & $\mathbf{0 , 8 7 1}$ \\
\hline PI2 & 0,349 & 0,435 & 0,494 & $\mathbf{0 , 8 8 7}$ \\
\hline PI3 & 0,315 & 0,374 & 0,471 & $\mathbf{0 , 8 4 2}$ \\
\hline Sumber & & & \\
\hline
\end{tabular}

Sumber : Lampiran 
Tabel 4.5 Hasil Uji Reliabilitas

\begin{tabular}{|l|l|l|}
\hline Variabel & $\begin{array}{l}\text { Cronbach's } \\
\text { Alpha }\end{array}$ & Composite Reliability \\
\hline Perceived Quality & 0,601 & 0,790 \\
\hline Brand Image & 0,764 & 0,848 \\
\hline Brand Trust & 0,693 & 0,812 \\
\hline Purchase Intention & 0,835 & 0,901 \\
\hline
\end{tabular}

Sumber: Lampiran

\section{Uji Multikolinearitas (Multicollinearity)}

Tabel 4.6 Nilai VIF

\begin{tabular}{|c|l|c|c|}
\hline \multicolumn{2}{|c|}{ Keterangan } & Nilai VIF & Keterangan \\
\hline Collinearity & PQ $\rightarrow$ PI & 1,818 & $\begin{array}{c}\text { Tidak ada } \\
\text { multikolinearitas }\end{array}$ \\
\hline Collinearity & BI $\rightarrow$ PI & 1,967 & $\begin{array}{c}\text { Tidak ada } \\
\text { multikolinearitas }\end{array}$ \\
\hline Collinearity & BT $\rightarrow$ PI & 2,090 & $\begin{array}{c}\text { Tidak ada } \\
\text { multikolinearitas }\end{array}$ \\
\hline
\end{tabular}

Sumber: lampiran

Tabel 4.7 Hasil Uji Bootstrapping

\begin{tabular}{|l|c|c|c|}
\hline \multicolumn{1}{|c|}{ Variabel } & Path coefficient & T-statistics & p-value \\
\hline $\begin{array}{l}\text { Perceived Quality } \longrightarrow \text { Purchase } \\
\text { Intention }\end{array}$ & 0,041 & 0,609 & 0,543 \\
\hline $\begin{array}{l}\text { Brand Image } \longrightarrow \text { Purchase } \\
\text { Intention }\end{array}$ & 0,114 & 1,406 & 0,160 \\
\hline $\begin{array}{l}\text { Brand Trust } \longrightarrow \text { Purchase } \\
\text { Intention }\end{array}$ & 0,501 & 7,016 & 0,000 \\
\hline
\end{tabular}

Sumber: lampiran

Tabel 4.7 Hasil Uji Effect Size $\left(f^{2}\right)$

\begin{tabular}{|c|c|c|c|c|}
\hline Variabel & PQ & BI & BT & PI \\
\hline PQ & & & & 0,002 \\
\hline BI & & & & 0,011 \\
\hline BT & & & & 0,188 \\
\hline
\end{tabular}

Menurut Ghozali dan Latan (2015) teknik analisa $f^{2}$ digunakan untuk mengetahui seberapa besar pengaruh konstruk tertentu terhadap variabel dependen.

\section{DISKUSI}

Pengujian hipotesis pertama (H1) tidak ditolak, karena perceived quality memiliki pengaruh yang positif terhadap purchase intention pada produk susu halal Milo di Jakarta. 
Pengujian hipotesis kedua $(\mathrm{H} 2)$ tidak ditolak, karena brand image memiliki pengaruh yang positif terhadap purchase intention pada produk susu halal Milo di Jakarta. Pengujian hipotesis ketiga (H3) tidak ditolak, karena brand trust memiliki pengaruh yang positif terhadap purchase intention pada produk susu halal Milo di Jakarta.

\section{KESIMPULAN}

Disarankan bagi perusahaan Nestle untuk meningkatkan reputasi yang baik dibanding para pesaing, serta memperhatikan kualitas produknya, dan menjaga kepercayaan konsumen sehingga dapat meningkatkan purchase intention konsumen terhadap produk susu halal Milo .Diharapkan bagi para peneliti lain untuk memakai variabel-variabel lain yang dapat memberikan pengaruh positif terhadap purchase intention. Diharapkan bagi para peneliti selanjutnya untuk menambah responden dalam penelitian sebagai alat ukur untuk kuesioner sehingga dapat memberikan lebih banyak lagi solusi bagi perusahaan-perusahaan yang membutuhkannya. selain itu disarankan juga bagi Nestle agar dapat meningkatkan kandungan gizi pada produk susu halal Milo.

\section{DAFTAR PUSTAKA}

Ali, A., Xiaoling, G., Sherwani, M., \& Ali, A. (2018). Antecedents of consumers' Halal brand purchase intention: an integrated approach. Management Decision.

Becerra, Enrique P., and Pradeep K. Korgaonkar (2011). "Effects of trust beliefs on consumers' online intentions." European Journal of marketing, 45(6), 936-962.

Fan, Q. (2019). Relationship among China's country image, corporate image and brand image: A Korean consumer perspective. Journal of Contemporary Marketing Science, 2(1), 34-49.

Ghozali, H.I., \& Latan, H. (2015). Partial Least Squares Konsep, teknik dan aplikasi menggunakan program SmartPLS 3.0 untuk penelitian empiris Edisi 2. Semarang: Badan penerbit Universitas Diponegoro Semarang.

Hendri, H. B. Pengaruh Brand Image, Brand Trust, Ewom Terhadap Purchase Intention Pada Produk H\&M Pada Masa Pandemi Covid-19. Jurnal Manajerial Dan Kewirausahaan, 3(2), 371-379.

Inka, H., \& Orrensalo, T. Brand image as a facilitator of relationship initiation: case studies from business practice. Koporcic, N., Ivanova-Gongne, M., Nyström, A.-G., Törnroos, J.-A.(eds.) Developing Insights on Branding in the B2B Context: Case Studies from Business Practice, 97-112.

Jalilvand, M. R., \& Samiei, N. (2012). The effect of electronic word of mouth on brand image and purchase intention: An empirical study in the automobile industry in Iran. Marketing Intelligence \& Planning.

Jiménez, Nadia, and Sonia San Martín. "The mediation of trust in country-of-origin effects across countries." Cross Cultural Management (2014).

Kwon, J. H., Jung, S. H., Choi, H. J., \& Kim, J. (2020). Antecedent factors that affect restaurant brand trust and brand loyalty: focusing on US and Korean consumers. Journal of Product \& Brand Management 
Li, Y., Teng, W., Liao, T. T., \& Lin, T. M. (2020). Exploration of patriotic brand image: its antecedents and impacts on purchase intentions. Asia Pacific Journal of Marketing and Logistics.

Ruslim, T. S., \& Andrew, R. (2012). Pengaruh brand image dan product knowledge terhadap purchase intention (Kasus: kosmetik merk "X"). Jurnal Manajerial dan Kewirausahaan.

Sugiyono (2019). Metode Penelitian Kuantitatif, Kualitatif, R\&D. Bandung: Alfabeta

Wang, Y., Wiegerinck, V., Krikke, H., \& Zhang, H. (2013). Understanding the purchase intention towards remanufactured product in closed-loop supply chains. International Journal of Physical Distribution \& Logistics Management, 43(10), 866-888.

Yaseen, S., \& Mazahir, I. (2019). Impact of corporate credibility, brand awareness, brand image and brand loyalty on purchase intention in the telecommunication sector of Karachi. Global Management Journal for Academic \& Corporate Studies, 9(1), 86-99.

Yusof, Y. L. M., Jusoh, W. J. W., \& Maulan, S. (2020). Perceived quality association as determinant to re-patronise Shariah-compliant brand restaurants. Journal of Islamic Marketing, 12(2), 302-315.

https://www.topbrand-award.com/ 